\title{
Effects of inhibitors of protein synthesis on the ovulatory process of the perfused rat ovary
}

\author{
M. Brännström, B. M. Boberg, J. Törnell, P. O. Janson* and K. Ahrén
}

Departments of Physiology and of * Obstetrics and Gynaecology, University of Göteborg, Box 33031, S-40033, Göteborg, Sweden

\begin{abstract}
Summary. The effects of two different protein synthesis inhibitors (cycloheximide and puromycin) on the ovulatory process were examined in vitro using a perfused rat ovary model. Ovaries of PMSG (20 i.u.)-primed rats were perfused for $21 \mathrm{~h}$. Release of cyclic adenosine $3^{\prime}, 5^{\prime}$-monophosphate (cAMP) and steroids (progesterone, testosterone, and oestradiol) was measured and the number of ovulations was estimated by counting released oocytes. Unstimulated control ovaries did not ovulate whereas addition of $\mathrm{LH}$ $(0 \cdot 1 \mu \mathrm{g} / \mathrm{ml})$ plus 3 -isobutyl-1-methylxanthine (IBMX; $0.2 \mathrm{mM}$ ) resulted in $16.7 \pm 3.5$ ovulations per treated ovary. Cycloheximide $(5 \mu \mathrm{g} / \mathrm{ml})$ totally inhibited the ovulatory effect of LH + IBMX when present from the beginning of the perfusions and also when added $8 \mathrm{~h}$ after LH + IBMX. No inhibition was seen when cycloheximide was added $10 \mathrm{~h}$ after $\mathrm{LH}+$ IBMX $(1-1 \cdot 5 \mathrm{~h}$ before the first ovulation; $15 \cdot 2 \pm 4 \cdot 4$ ovulations per treated ovary). Puromycin $(200 \mu \mathrm{g} / \mathrm{ml})$ completely blocked ovulation when present from the beginning of the perfusions and the inhibition was $\simeq 60 \%(6.5 \pm 2.2$ ovulations per treated ovary) when the compound was added $8 \mathrm{~h}$ after LH + IBMX. Both inhibitors increased LH + IBMX-stimulated cAMP release substantially, but decreased the release of progesterone, testosterone and oestradiol. These results indicate that de-novo protein synthesis is important late in the ovulatory process for follicular rupture to occur.
\end{abstract}

Keywords: cycloheximide; ovulation; perfusion; protein synthesis; puromycin; rat

\section{Introduction}

The preovulatory surge of luteinizing hormone $(\mathrm{LH})$ initiates a series of biochemical events leading to oocyte maturation, follicular rupture, and luteinization of the follicle (LeMaire et al., 1979). Shortly after the LH surge there is an increase in ovarian protein synthesis (Wang \& Greenwald, 1985) which is essential for the stimulation of steroidogenesis (Lieberman et al., 1975; Greenwald \& Limback, 1984) and oocyte maturation (Tsafriri et al., 1973). This change in protein synthesis may also be important for ovulation, since inhibitors of protein synthesis administered in vivo can inhibit ovulation in the rabbit (Pool \& Lipner, 1966; Espey, 1986), the hamster (Alleva et al., 1979; Wang \& Greenwald, 1985) and the rat (Espey et al., 1985). However, in these studies discrepancies were noted regarding the optimum time of administration. Furthermore, protein synthesis inhibitors are known to induce toxic syndromes (Young et al., 1963) and such conditions may influence the ovulatory process in vivo. To avoid such gross effects of protein synthesis inhibitors, we have examined the action of two chemically different inhibitors of protein synthesis on ovulation in a well-characterized in-vitro perfusion system (Janson et al., 1982) which has been used to perfuse rat ovaries (Koos et al., 1984a; Brännström et al., 1987a). In parallel, the production of cyclic AMP and steroids was monitored to define the influence of inhibition of protein synthesis on these steps in the ovulatory process. 


\section{Materials and Methods}

Animals and surgical procedure. Immature, female Sprague-Dawley rats (ALAB, Stockholm, Sweden) were kept under controlled conditions ( $14 \mathrm{~h}$ light and $10 \mathrm{~h}$ dark) and offered pelleted food and water ad libitum. In the morning of Day 28 of age, the rats were primed with a s.c. injection of $20 \mathrm{i}$.u. PMSG to induce follicular growth and differentiation. The surgical procedure and preparation of the ovary have been described in detail elsewhere (Koos et al., 1984a). Briefly, the rats were anaesthetized in the morning of Day 30 of age, by i.p. injection of ketamine ( $125 \mathrm{mg} / \mathrm{kg}$ body wt; Parke Davis, Morris Plains, NY, USA). After i.v. injection of 200 i.u. heparin sulphate (Löwen, Helsingborg, Sweden), a laparotomy was performed. The renal and iliolumbar vessels were ligated and severed and then the abdominal part of the aorta and the vena cava were cannulated in a retrograde direction. All other connecting vessels except the right ovarian vein and artery were then ligated and severed. After ligations of the aorta and the vena cava cranial to the branching of the ovarian vessels and caudal to the site of cannulation, the preparation was removed and perfused with $0.154 \mathrm{M}-\mathrm{NaCl}$ to wash out blood before connection to the perfusion apparatus.

Perfusion procedure. The perfusion apparatus and procedure have been described in detail elsewhere (Janson et al., 1982; Brännström et al., 1987a). The ovaries were perfused for up to $21 \mathrm{~h}$ in a recirculating system containing $70 \mathrm{ml}$ Medium M199 with Earle's salts (Gibco, Paisley, UK) supplemented with $0 \cdot 2$ i.u. heparin sulphate/ $\mathrm{ml}$ (Löwen, Helsingborg, Sweden), 0.02 i.u. insulin/ml (Novo, Copenhagen, Denmark), $5 \mu \mathrm{g}$ gentamicin sulphate/ $\mathrm{ml}$ (Sigma Chemical Company, St Louis, MO, USA) and $4 \%$ fraction $\mathrm{V}$ bovine serum albumin (BoehringerMannheim, Mannheim, FDR). The temperature of the perfusion medium was kept at $37^{\circ} \mathrm{C}$ and the $\mathrm{pH}$ was maintained at 7.4 by continuous gassing with $5 \% \mathrm{CO}_{2}$ in $95 \% \mathrm{O}_{2}$. The perfusion pressure was kept at 60 $80 \mathrm{~mm} \mathrm{Hg}$ and the flow of the perfusate was checked every $30 \mathrm{~min}$ up to $7 \mathrm{~h}$. The average flow was $0.8 \mathrm{ml} / \mathrm{min}$. Samples $(1.5 \mathrm{ml})$ of perfusion medium were taken for analysis of cAMP and steroids at the times indicated in Fig. 1. Fresh medium $(1.5 \mathrm{ml})$ was always added to the perfusion system immediately after a sample was taken. Ovulated oocytes were counted and examined under a Nomarski interference microscope after termination of the perfusion. Ova with germinal vesicles (GV) were considered to be immature and those with germinal vesicle breakdown (GVB) as maturing (Tsafriri \& Kraicer, 1972).

Hormones and chemicals. Ovine luteinizing hormone (NIH-LH-o24) and PMSG were kindly provided by the NIADDK, Bethesda, MD, USA. IBMX (3-isobutyl-1-methylxanthine), cycloheximide and puromycin were purchased from Sigma Chemical Company, St Louis, MO, USA. L- $\left[{ }^{14} \mathrm{C}\right]$ leucine (sp. act. $342 \mathrm{mCi} / \mathrm{mmol}$ ) was bought from Amersham plc, Amersham, UK. All hormones and chemicals were dissolved in medium before addition to the perfusion system.

Assay of protein synthesis. Protein synthesis was estimated by measuring the incorporation of $\mathrm{L}-\left[{ }^{14} \mathrm{C}\right]$ leucine. Ovaries were perfused for $1 \mathrm{~h}$ before $\mathrm{LH}(0.1 \mu \mathrm{g} / \mathrm{ml})$ and IBMX $(0.2 \mathrm{mM})$ were added. Cycloheximide $(5 \mu \mathrm{g} / \mathrm{ml})$ or puromycin $(200 \mu \mathrm{g} / \mathrm{ml})$ were present in the medium from the start of the perfusions. At $2 \mathrm{~h}$ after addition of LH + IBMX, the ovaries were transferred to other perfusion systems containing medium identical to that in the first perfusions plus $\mathrm{L}-\left[{ }^{14} \mathrm{C}\right]$ leucine $(0 \cdot 3 \mu \mathrm{Ci} / \mathrm{ml})$ and perfused for an additional $1 \mathrm{~h}$. The ovaries were homogenized in $1.5 \mathrm{ml} 5 \%$ trichloroacetic acid (TCA) and centrifuged at $1000 \mathrm{~g}$ for $10 \mathrm{~min}$. The pellets were dissolved in $3 \mathrm{ml} 5 \%$ TCA with $1 \%$ unlabelled L-leucine and heated at $85^{\circ} \mathrm{C}$ for $15 \mathrm{~min}$, followed by centrifugation at $1000 \mathrm{~g}$ for $10 \mathrm{~min}$. The pellets were washed in $3 \mathrm{ml}$ ethanol-chloroform-diethylether (3:2:1; by vol.) followed by centrifugation for $10 \mathrm{~min}$ at $1000 \mathrm{~g}$, a procedure which was repeated three times. Finally, the precipitates were washed in $2 \mathrm{ml}$ diethyl ether, dried and dissolved in $1 \mathrm{ml} 1 \mathrm{M}-\mathrm{NaOH}$. Protein concentration was measured by the method of Lowry et al. (1951). Finally, $100 \mu \mathrm{l}$ of this solution were mixed with $3 \mathrm{ml}$ Opti Safe scintillation fluid (LKB, Loughborough, UK) and counted. Incorporation was expressed as c.p.m./mg protein.

Steroid and cAMP assays. Progesterone, testosterone and oestradiol concentrations were measured by radioimmunoassays (Hillensjö et al., 1976; Hedin et al., 1983) using specific antisera obtained from Immuno-Chemicals, Tumba, Sweden. The cross-reactivities of the specific antisera with other steroids were as follows: progesterone, $6 \cdot 7 \%$ with $17 \alpha$-hydroxyprogesterone, $0.4 \%$ with pregnenolone, $0.1 \%$ with testosterone, and $<0.001 \%$ with oestradiol; oestradiol, $0.2 \%$ with oestriol, and $<0.1 \%$ with progesterone and testosterone; testosterone, $4 \%$ with androstenedione, $0.1 \%$ with oestradiol, and $<0.001 \%$ with progesterone. Intra-assay and inter-assay coefficients of variation in the progesterone, testosterone and oestradiol assays were $11 \%$ and $15 \%, 10 \%$ and $10 \%, 10 \%$ and $9 \%$, respectively, and the sensitivities were $4 \mathrm{pg}$ progesterone, $5 \mathrm{pg}$ testosterone and $4 \mathrm{pg}$ oestradiol.

Cyclic AMP levels in the medium were determined by a protein binding assay (Gilman, 1970) with minor modifications (Holmes et al., 1986). The sensitivity of the assay was $0.5 \mathrm{pmol}$ and the intra-assay coefficient of variation was $15 \%$.

Vital staining of oocytes. A stock solution of $5 \mathrm{mg}$ fluorescein-diacetate/ml (FDA; Sigma) in acetone was prepared. The solution was diluted $10^{4}$ times in Eagles MEM with Earle's salts (Gibco, Paisley, UK) immediately before staining. Oocyte-cumulus complexes were mechanically isolated from follicles of perfused ovaries and incubated for $5 \mathrm{~min}$ 
in FDA followed by washing in $1 \mathrm{ml}$ plain medium for $5 \mathrm{~min}$. Cells that have esterase will hydrolyse the hydrophobic FDA molecule to a more hydrophilic fluorescein molecule, which will be trapped within the cell if the cell membrane remains intact (Rotman \& Papermaster, 1966). Viable cells with trapped fluorescein were visualized with a fluorescence-microscope with an excitation filter between 450 and $490 \mathrm{~nm}$ and a barrier filter at $520 \mathrm{~nm}$.

Experimental groups. The experimental design and different treatment groups are shown in Table 1.

Statistics. Results are presented as means \pm s.e.m. Statistical differences were evaluated by using the KruskalWallis test with multiple comparisons (Theodorsson-Norheim, 1986).

Table 1. Experimental groups

\begin{tabular}{|c|c|c|c|c|c|c|}
\hline \multirow[b]{2}{*}{ Group no. } & \multirow{2}{*}{$\begin{array}{l}\text { No. of } \\
\text { ovaries }\end{array}$} & \multicolumn{5}{|c|}{ Additions to the perfusion medium } \\
\hline & & At $-1 \mathrm{~h}$ & At $0 \mathrm{~h}$ & At $2 \mathrm{~h}$ & At $8 \mathrm{~h}$ & At $10 \mathrm{~h}$ \\
\hline 21 h perfusion* & & & & & & \\
\hline I & 6 & - & $\mathrm{H}+\overline{\mathrm{IBMXS}}$ & 一 & 一 & 一 \\
\hline II & 6 & Cuchimide & LH + IBMX§ & - & - & - \\
\hline III & 6 & Cycloheximide $\uparrow$ & LH + IBMX & - & - & - \\
\hline IV & 6 & - & LH + IBMX & - & Cycloheximide & - \\
\hline V & 6 & - & LH + IBMX & - & - & Cycloheximide \\
\hline VI & 6 & Puromycin\| & LH + IBMX & - & - & - \\
\hline VII & 6 & - & LH + IBMX & - & Puromycin & - \\
\hline $\begin{array}{l}11 \mathrm{~h} \text { perfusion } \dagger \\
\text { VIII }\end{array}$ & 4 & Cycloheximide & - & - & - & - \\
\hline $\begin{array}{l}4 \mathrm{~h} \text { perfusion }{ }_{+}^{+} \\
\text {IX }\end{array}$ & 4 & - & $\mathrm{LH}+\mathrm{IBMX}$ & $L-\left[{ }^{14} \mathrm{Clleucinet+}\right.$ & & \\
\hline $\mathrm{X}$ & 4 & Cycloheximide & LH + IBMX & $\mathrm{L}-\left[{ }^{14} \mathrm{C}\right]$ leucine & & \\
\hline XI & 4 & Puromycin & LH + IBMX & $\mathrm{L}-\left[{ }^{14} \mathrm{C}\right]$ leucine & & \\
\hline
\end{tabular}

${ }^{*}$ Groups I-VII represent studies of ovulation, cAMP release and steroid release.

† Group VIII represents studies of cAMP release.

† Groups IX-XI represent studies of incorporation of $\mathrm{L}-\left[{ }^{14} \mathrm{C}\right]$ leucine.

$\S \mathrm{LH}(0 \cdot 1 \mu \mathrm{g} / \mathrm{ml})+\operatorname{IBMX}(0 \cdot 2 \mathrm{mM})$.

ๆ Cycloheximide $(5 \mu \mathrm{g} / \mathrm{ml})$.

$\|$ Puromycin $(200 \mu \mathrm{g} / \mathrm{ml})$.

$\dagger_{\dagger L}-\left[{ }^{14} \mathrm{C}\right]$ leucine $(0 \cdot 3 \mu \mathrm{Ci} / \mathrm{ml})$.

\section{Results}

\section{Effects of protein synthesis inhibitors on number of ovulations}

Treatment with LH $(0 \cdot 1 \mu \mathrm{g} / \mathrm{ml})+\operatorname{IBMX}(0 \cdot 2 \mathrm{mM}$; Group II) resulted in a large number of ovulations $(16.7 \pm 3.5$ ovulations per treated ovary; the first ovulations occurring $11-11.5 \mathrm{~h}$ after addition of LH + IBMX), in contrast to unstimulated control ovaries, from which no ovulation occurred (Table 2). Cycloheximide $(5 \mu \mathrm{g} / \mathrm{ml})$ totally blocked LH + IBMX-stimulated ovulation in 5 of 6 ovaries, when present from the beginning of the perfusions (Group III) and in all 6 ovaries when added $8 \mathrm{~h}$ after LH + IBMX (Group IV). When cycloheximide was added $10 \mathrm{~h}$ after LH + IBMX (Group V), no significant $(P>0.05)$ inhibition of ovulation was seen, when compared to Group II. Puromycin $(200 \mu \mathrm{g} / \mathrm{ml})$ completely inhibited LH + IBMX-stimulated ovulation, when present in the medium from the beginning of the perfusions (Group VI), but only partly $(6.5 \pm 2.2$ ovulations per treated ovary) when added at $8 \mathrm{~h}$ after LH + IBMX (Group VII). 
Table 2. Ovulations in rat ovaries perfused in vitro

\begin{tabular}{lccccc}
\hline & & & & \multicolumn{2}{c}{$\begin{array}{c}\text { No. (mean } \pm \text { s.e.m.) of } \\
\text { ovulations }\end{array}$} \\
\cline { 5 - 7 } Treatment groups & $\begin{array}{c}\text { No. of } \\
\text { ovaries }\end{array}$ & $\begin{array}{c}\text { No. of } \\
\text { ovulating } \\
\text { ovaries }\end{array}$ & $\begin{array}{c}\text { Range of } \\
\text { ovulations }\end{array}$ & $\begin{array}{c}\text { Per ovulating } \\
\text { ovary }\end{array}$ & $\begin{array}{c}\text { Per treated } \\
\text { ovary }\end{array}$ \\
\hline I Control & 6 & 0 & - & & 0 \\
II LH + IBMX & 6 & 6 & $8-30$ & $16 \cdot 7 \pm 3 \cdot 5$ & $16 \cdot 7 \pm 3 \cdot 5$ \\
III LH + IBMX + cycloheximide - I h & 6 & 1 & $0-1$ & 1 & 0.2 \\
IV LH + IBMX + cycloheximide 8h & 6 & 0 & - & & 0 \\
V LH + IBMX + cycloheximide 10 h & 6 & 6 & $6-35$ & $15 \cdot 2 \pm 4 \cdot 4$ & $15 \cdot 2 \pm 4 \cdot 4$ \\
VI LH + IBMX + puromycin -1 h & 6 & 0 & - & -13 & 0 \\
VIILH + IBMX + puromycin $8 \mathrm{~h}$ & 6 & 5 & $0-13$ & $7 \cdot 1 \pm 2 \cdot 2$ & $6 \cdot 5 \pm 2 \cdot 2$ \\
\hline
\end{tabular}

Effects of cycloheximide and puromycin on protein synthesis

The $\mathrm{LH}+$ IBMX-stimulated incorporation of $\mathrm{L}-\left[{ }^{14} \mathrm{C}\right]$ leucine into ovarian proteins $(1713 \pm 94$ c.p.m./mg protein) was clearly inhibited by addition of cycloheximide $(10 \pm 2$ c.p.m./ $\mathrm{mg}$ protein) or puromycin $(65 \pm 22$ c.p.m./mg protein $)$.

\section{Effects of protein synthesis inhibitors on cyclic AMP levels in the perfusion medium}

Cyclic AMP levels in the perfusion media of Groups I, II, III, VI (Fig. 1a) and VIII were measured up to $10 \mathrm{~h}$. Control ovaries (Group I) showed a minimal release of cAMP into the perfusion medium, whereas stimulation with LH + IBMX (Group II) resulted in a clear increase in cAMP release. The presence of cycloheximide (Group III) or puromycin (Group VI) markedly potentiated the LH + IBMX-stimulated cAMP release. Additional experiments were performed to establish whether the potentiating effect on cAMP release of cycloheximide was acting independently of LH (Group VIII). Cycloheximide added alone at $-1 \mathrm{~h}$ did not stimulate the cAMP release to levels above those of the control group (Group I) at any time point (highest levels in Group VIII being $2.9 \pm 0.4 \mathrm{pmol} / \mathrm{ml}$ at $2 \mathrm{~h}$ compared to highest levels in Group I being $3 \cdot 6 \pm 1 \cdot 2 \mathrm{pmol} / \mathrm{ml}$ at $5 \mathrm{~h}$ ).

\section{Effects of protein synthesis inhibitors on steroid levels in the perfusion medium}

The concentrations in the perfusion medium of progesterone, testosterone and oestradiol in the different treatment groups are shown in Figs 1(b)-(d). A small increase of progesterone, testosterone and oestradiol in the perfusion medium throughout the perfusions was seen in Group I (no LH + IBMX). Treatment with LH + IBMX (Group II) caused a rapid increase in steroid release with a termination of testosterone and oestradiol release $3-5 \mathrm{~h}$ after treatment. Progesterone reached plateau levels in the perfusion medium after $\simeq 3 \mathrm{~h}$. This indicates a continued production of progesterone, as the levels in the perfusion medium remained high in spite of a marked adsorption of progesterone. In this perfusion system, progesterone is readily adsorbed to the system with a $\mathrm{t}_{\frac{1}{2}}$ of about $2.5 \mathrm{~h}$ in contrast to testosterone and oestradiol which show minimal adsorption (for further details, see Brännström et al., 1987a). The presence of cycloheximide in the perfusion medium resulted in a decrease in release of all steroids. Puromycin caused an even more pronounced decrease.

Steroid levels were statistically compared at $10 \mathrm{~h}$, a time which is close to the first ovulation. At this time there were significantly $(P<0.01)$ lower concentrations of progesterone, testosterone and oestradiol in Groups III and VI than in Group II. There were no significant $(P>0.05)$ changes in 


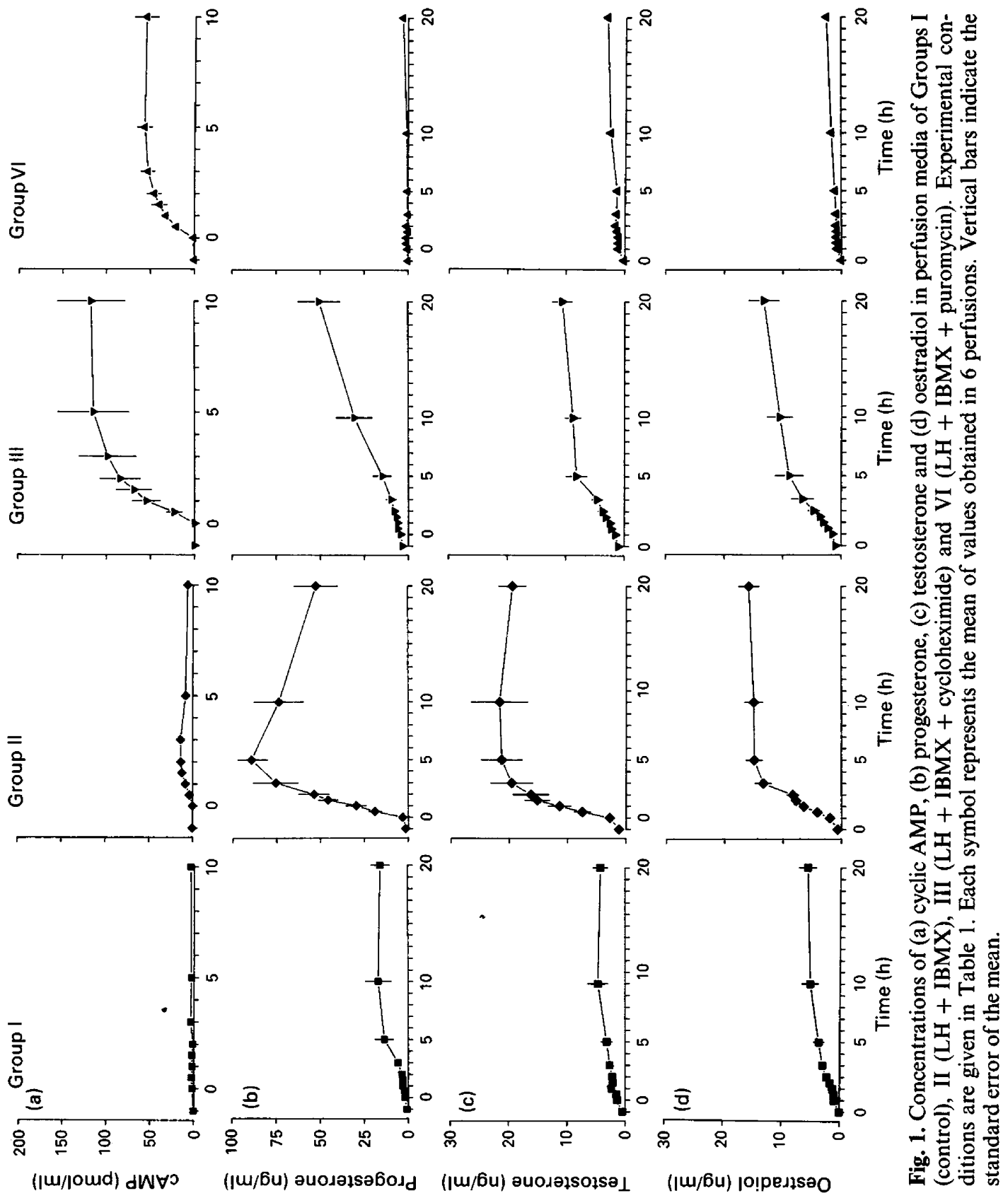


steroid levels of Groups IV, V or VII, when the concentrations at time points after additions of protein synthesis inhibitors were compared with the concentrations at the time point before.

\section{General observations}

No changes were seen in the flow of the perfusate following addition of either substance. Vital staining of oocyte-cumulus complexes, mechanically isolated from perfused $(21 \mathrm{~h})$ ovaries from Groups I, II, III and VI (2-3 oocytes from two ovaries in each group) appeared normal (fluorescence intensity similar to that of oocyte-cumulus complexes isolated in the morning of induced oestrus from ovaries of PMSG (20 i.u.)-primed rats). Of the ovulated oocytes in Groups II, V and VII, 15-25\% showed maturation (GVB).

\section{Discussion}

Cycloheximide and puromycin inhibit protein synthesis by different mechanisms. Cycloheximide inhibits translation by a specific inhibition of the synthesis of ribosomal and transfer RNA (Gokal et al., 1986). Puromycin acts by competing with aminoacyl-transfer RNA for the site on the $50 \mathrm{~S}$ subunit of the ribosome, causing premature amino acid chain termination (Pestka, 1971). The present study and earlier studies (Ahrén et al., 1968; Tsafriri et al., 1973) showed that cycloheximide and puromycin in the concentrations used here are effectively inhibiting ovarian protein synthesis in vitro.

The results of the present study clearly demonstrate that both these compounds can inhibit ovulation in the isolated perfused rat ovary. Earlier experiments with in-vivo administration of protein synthesis inhibitors have shown that these substances are most effective when administered before or soon after the ovulatory hCG injection and ineffective if added late in the preovulatory period (Pool \& Lipner, 1966; Alleva et al., 1979; Espey et al., 1985; Espey, 1986). The inhibition of ovulation in these in-vivo studies is probably due to inhibition of protein synthesis late during the follicular development or early in the ovulatory process. However, the present study shows that cycloheximide is able to suppress ovulation almost totally even when added to the perfusion system as late as $8 \mathrm{~h}$ after treatment with $\mathrm{LH}+$ IBMX. When added at $10 \mathrm{~h}(\mathrm{l}-2 \mathrm{~h}$ before the first expected ovulation) no inhibition is seen. Puromycin also inhibits ovulation completely when present from the beginning of the perfusions and is partly effective when added $8 \mathrm{~h}$ after LH + IBMX. The difference in results between in-vivo and in-vitro experiments is at present unclear and may be explained by differences in dosages used or discrepancies in time between drug administration and effect on the ovary. Both inhibitors of protein synthesis increase the cyclic AMP release into the perfusion medium and decrease the steroid release. No signs of devitalization of the tissue are seen, as indicated by normal vital staining of oocyte-cumulus complexes after perfusion for $21 \mathrm{~h}$ and a continued release of cAMP and steroids into the medium.

The induction of cAMP production appears to be a crucial early step in the ovulatory process. Holmes et al. (1986) were able to induce ovulations in the isolated perfused rabbit ovary by forskolin, a non-specific activator of adenylate cyclase. Brännström et al. (1987b) could induce ovulations in perfused rat ovaries by adding dibutyryl cAMP and the phosphodiesterase inhibitor IBMX to the medium. In the present study, addition of protein synthesis inhibitors increases cAMP release. A clear conclusion from our data is therefore, that the protein synthesis inhibitors block ovulation by a mechanism of action beyond adenylate cyclase. The increase of cAMP confirms earlier observations using other experimental preparations such as incubated rat follicles (Lamprecht $e t$ al., 1977) and prepubertal rat ovaries (Bergh \& Ahrén, 1980). The increased release of cAMP into the medium is most likely due to an increased production of the nucleotide rather than an inhibition of the activity of the cAMP-degrading phosphodiesterase enzyme, as indicated by a persistence of the effect in the presence of IBMX (Bergh \& Ahrén, 1980) and failure of cycloheximide treatment 
to produce any significant change in phosphodiesterase activity in thyroid cells (Rapoport \& Adams, 1976). The increased synthesis of cAMP could be explained by an inhibition of synthesis of inhibitory proteins which normally reduce adenylate cyclase activity at gonadotrophin-induced desensitization (Hedin \& Ahrén, 1983). The results in the present study showing no effect of cycloheximide by itself on cAMP release confirm findings on incubated prepubertal rat ovaries $(K$. Ahrén \& C. Bergh, unpublished data) and show that the stimulation of cAMP release by the protein synthesis inhibitor is only evident upon LH stimulation.

In the present study, $75-85 \%$ of the ovulated oocytes were immature when examined at the end of the perfusions. This finding is in line with earlier results from in-vitro incubated rat follicles (Lindner et al., 1974; Hillensjö et al., 1978), in which addition of phosphodiesterase inhibitors together with $\mathbf{L H}$ arrested the normal $\mathrm{LH}$-induced stimulation of meiosis. The arrested meiosis is probably due to a prolonged increase in intracellular cAMP levels in the oocyte-cumulus complex (Cho et al., 1974). This is further supported by our earlier findings (unpublished) that more than $90 \%$ of the ovulated oocytes from ovaries stimulated with LH + IBMX mature spontaneously if transferred to control medium and incubated for $4 \mathrm{~h}$.

An early step in the chain of preovulatory events is the LH-induced increase in follicular steroid production. The importance of this increase in steroidogenesis for follicular rupture is a matter of controversy. In contrast to reports from experiments in vivo on the rat (Snyder et al., 1984) and the sheep (Murdoch et al., 1986) indicating an important role for progesterone, Holmes et al. (1985) were unable to affect the ovulation rate in perfused rabbit ovaries by treatment with an inhibitor of $3 \beta$-hydroxysteroid dehydrogenase, which converts pregnenolone to progesterone. However, our data (Brännström \& Janson, 1988) for the perfused rat ovary seem to indicate that high progesterone levels are of importance for ovulation in the rat, and species differences might therefore exist. Androgens (Mori et al., 1977), in contrast to oestrogens (Lipner \& Wendelken, 1971; Koos et al., 1984b), have also been suggested to play a role in the ovulatory process. In the present study, inhibition of protein synthesis resulted in a decreased release of the three steroids measured. A shortage of steroid precursors has been suggested to explain the cycloheximide-induced inhibition of steroidogenesis in the hamster (Greenwald \& Limback, 1984). In rat luteal tissue, a cycloheximide-inhibitable process forming the key step in regulating the availability of mitochondrial cholesterol to the side-chain cleavage system has been described (Toaff et al., 1979). The various steps in steroidogenesis beyond $3 \beta$-hydroxysteroid dehydrogenase have been reported to be unaffected in cycloheximide-treated granulosa cells (Greenwald \& Limback, 1984). In the present study, cycloheximide inhibited ovulation when added at $8 \mathrm{~h}$ after LH + IBMX, a time well after the shut down of testosterone and oestradiol release but with a continued output of progesterone. A possible mechanism of action for the ovulation-blocking properties of protein synthesis inhibitors could, therefore, be specific interference with progesterone production.

Prostaglandins are considered to play a key role in the ovulatory process (for review, see Armstrong, 1981). The increase in prostaglandin concentrations in the rat ovary occurs after a lag phase of $2-4 \mathrm{~h}$ after $\mathrm{LH}$ stimulation and maximal levels are seen around the time of ovulation (Bauminger et al., 1978). Inhibition of protein synthesis may interfere with arachidonic acid release (Pong et al., 1977 ) or with later steps in prostaglandin biosynthesis. High levels of prostaglandin endoperoxidase synthase, a key enzyme in the cyclo-oxygenase pathway of arachidonic acid metabolism, are detected in granulosa cells of preovulatory follicles $7 \mathrm{~h}$ after hCG injection in vivo (Hedin et al., 1987) or $7 \mathrm{~h}$ after addition of LH + IBMX to the in-vitro perfused rat ovary (Hedin et al., 1988). The induction of enzymes in the prostaglandin pathway of arachidonic acid metabolism has therefore probably taken place before $8 \mathrm{~h}$, when addition of cycloheximide was still effective. It is therefore unlikely that the mechanism behind the late effects of protein synthesis inhibitors involves an interference with the induction of prostaglandin-synthesizing enzymes. However, it cannot be ruled out that the protein synthesis inhibitors lower prostaglandin synthesis by decreasing the availability of arachidonic acid (Pong et al., 1977).

Plasminogen activator levels within the ovary rise before ovulation and plasminogen activator 
has been suggested to be a mediator in the ovulatory process (Beers et al., 1975). Plasminogen activator converts plasminogen to plasmin, which in turn may activate latent collagenase to degrade collagen and thereby causing a weakening of the follicular wall (Reich et al., 1985). A late preovulatory activation of collagenase in the ovary has been verified (Curry et al., 1985) and inhibitors of collagenase are able to inhibit ovulation in the perfused rat ovary (Brännström et al., 1988). The most likely interpretation of our results is therefore that the late inhibition of ovulation seen with cycloheximide is due to inhibition of plasminogen activator production and collagenase activation.

In conclusion, the results from the present study show that inhibition of ovarian protein synthesis can block ovulation by affecting metabolic steps beyond cAMP, where an interference with production of progesterone or prostaglandins is possible but an interference with plasminogen activator and/or collagenase seems more likely.

We thank Ms Gun Derevall for careful typing of this manuscript and the National Hormone and Pituitary Program of the NIADDK for the generous gift of PMSG and LH. This study was supported by grants from the Swedish Medical Research Council (0027, 4982), the Göteborg Medical Society, and the Medical Faculty, University of Göteborg.

\section{References}

Ahrén, K., Hamberger, L. \& Rubinstein, L. (1968) Influence of puromycin and anoxia on the effect of gonadotrophins on ovarian carbohydrate metabolism. Acta physiol. scand. 74, 79-90.

Alleva, J.A., Bonventre, P.F. \& Lamanna, C. (1979) Inhibition of ovulation in hamsters by the protein synthesis inhibitors diphtheria toxin and cycloheximide. Proc. Soc. exp. Biol. Med. 162, 170-174.

Armstrong, D.T. (1981) Prostaglandins and follicular functions. J. Reprod. Fert. 62, 283-291.

Bauminger, S., Koch, Y., Khan, I., Hillensjö, T., Nilsson, L. \& Ahrén, K. (1978) Preovulatory changes in ovarian cyclic AMP and prostaglandins in immature rats injected with PMSG. J. Reprod. Fert. 52, 21-23.

Beers, W.H., Strickland, S. \& Reich, E. (1975) Ovarian plasminogen activator: relationship to ovulation and hormonal regulation. Cell 6, 387-394.

Bergh, C. \& Ahrén, K. (1980) Prolongation of the effects of gonadotrophins and prostaglandins $\mathrm{E}_{2}$ on ovarian cyclic AMP formation by inhibitors of protein synthesis. Acta endocr., Copenh. 94, 251-258.

Brännström, M. \& Janson, P.O. (1988) The involvement of progesterone in the ovulatory process of the in vitro-perfused rat ovary. Biol. Reprod. 38, Suppl. 1, Abstr. 38.

Brännström, M., Johansson, B.M., Sogn, J. \& Janson, P.O. (1987a) Characterization of an in vitro perfused rat ovary model: ovulation rate, oocyte maturation, steroidogenesis and influence of PMSG priming. Acta physiol. scand. 130, 107-111.

Brännström, M., Koos, R.D., LeMaire, W.J. \& Janson, P.O. (1987b) Cyclic adenosine 3',5' monophosphateinduced ovulation in the perfused rat ovary and its mediation by prostaglandins. Biol. Reprod. 37, 1047 1053.

Brännström, M., Woessner, J.F., Jr, Koos, R.D., Sear, C.H.J. \& LeMaire, W.J. (1988) Inhibitors of mammalian tissue collagenase and metalloproteinases suppress ovulation in the perfused rat ovary. Endocrinology 122, 1715-1721.

Cho, W.K., Stern, S. \& Biggers, J.D. (1974) Inhibitory effect of dibutyryl cAMP on mouse oocyte maturation in vitro. J. exp. Zool. 187, 383-386.

Curry, T.E., Jr, Dean, D.D., Woessner, J.F., Jr \& LeMaire, W.J. (1985) The extraction of a tissue collagenase associated with ovulation in the rat. Biol. Reprod. 33, 981-989.

Espey, L.L. (1986) Cycloheximide inhibition of ovulation, prostaglandin biosynthesis and steroidogenesis in rabbit ovarian follicles. $J$. Reprod. Fert. 78, 679 683.

Espey, L., Shimada, H., Okamura, H. \& Mori, T. (1985) Effect of various agents on ovarian plasminogen activator activity during ovulation in pregnant mare's serum gonadotropin-primed immature rats. Biol. Reprod. 32, 1087-1094.

Gilman, A.G. (1970) A protein binding assay for adenosine 3',5'-cyclic monophosphate. Proc. nain. Acad. Sci. U.S.A. 67, 305-312.

Gokal, P.K., Cavanaugh, A.H. \& Thompson, E.A., Jr (1986) The effects of cycloheximide upon transcription of rRNA, $5 \mathrm{~S}$ RNA, and tRNA genes. $J$. biol. Chem. 261, 2536-2541.

Greenwald, G.S. \& Limback, D. (1984) Effects of treatment with cycloheximide at proestrus on subsequent in vitro follicular steroidogenesis in the hamster. Biol. Reprod. 30, 1105-1116.

Hedin, L. \& Ahrén, K. (1983) Involvement of cyclic AMP and protein synthesis in the desensitization of the prepubertal rat ovary. Molec. cell. Endocr. 29, 335-347.

Hedin, L., Ekholm, C. \& Hillensjö, T. (1983) Doserelated effects of luteinizing hormone on the pattern of steroidogenesis and cyclic adenosine monophosphate release in superfused preovulatory rat follicles. Biol. Reprod. 29, 895-904.

Hedin, L., Gaddy-Kurten, D., Kurten, R., DeWitt, D.L., Smith, W.L. \& Richards, J.S. (1987) Prostaglandin 
endoperoxide synthase in rat ovarian follicles: content, cellular distribution, and evidence for hormonal induction preceding ovulation. Endocrinology 121, $722-731$.

Hedin, L., Brännström, M., Larson, L. \& Basta, B. (1988) Regulation of prostaglandin endoperoxide synthase (PGS) by cyclic AMP (cAMP) in rat ovarian follicles preceding ovulation in vitro. Endocrinology 122, Suppl. 289, Abstr. 1076.

Hillensjö, T., Bauminger, S. \& Ahrén, K. (1976) Effect of LH on the pattern of steroid production by preovulatory follicles of PMS-injected immature rats. Endocrinology 99, 996-1002.

Hillensjö, T., Ekholm, C. \& Ahrén, K. (1978) Role of cyclic AMP in oocyte maturation and glycolysis in the preovulatory rat follicle. Acta endocr., Copenh. 87, 377-388.

Holmes, P.V., Sogn, J., Schillinger, E. \& Janson, P.O. (1985) Effects of high and low preovulatory concentrations of progesterone on ovulation from the isolated perfused ovary. J. Reprod. Fert. 75, 393-399.

Holmes, P.V., Hedin, L. \& Janson, P.O. (1986) The role of cyclic adenosine $3^{\prime}, 5^{\prime}$-monophosphate in the ovulatory process of the in vitro perfused rabbit ovary. Endocrinology 118, 2195-2202.

Janson, P.O., LeMaire, W.J., Källfelt, B., Holmes, P.V., Cajander, S., Bjersing, L., Wiqvist, N. \& Ahrén, K. (1982) The study of ovulation in the isolated perfused rabbit ovary. I. Methodology and pattern of steroidogenesis. Biol. Reprod. 26, 456465.

Koos, R.D., Jaccarino, F.J., Magaril, R.A. \& LeMaire, W.J. (1984a) Perfusion of the rat ovary in vitro: methodology, induction of ovulation and pattern of steroidogenesis. Biol. Reprod. 30, 1135-1141.

Koos, R.D., Feiertag, M.A., Brodie, A.M.H. \& LeMaire, W.J. (1984b) Inhibition of estrogen synthesis does not inhibit luteinizing hormone-induced ovulation. Am. J. Obstet. Gynecol. 148, 939-943.

Lamprecht, S.A., Zor, U., Salomon, Y., Koch, Y., Ahrén, K. \& Lindner, H.R. (1977) Mechanism of hormonally induced refractoriness of ovarian adenylate cyclase to luteinizing hormone and prostaglandin $\mathrm{E}_{2} . J$. cycl . Nucleotide Res. 3, 69-83.

LeMaire, W.J., Clark, M.R. \& Marsh, J.M. (1979) Biochemical mechanism of ovulation. In Human Ovulation, pp. 159-175. Ed. E. S. E. Hafez. Elsevier/ North-Holland Biomedical Press, Amsterdam.

Lieberman, M.E., Barnea, A., Bauminger, S., Tsafriri, A., Collins, W.P. \& Lindner, H.R. (1975) LH effect on the pattern of steroidogenesis in cultured Graafian follicles of the rat: dependence on macromolecular synthesis. Endocrinology 96, 1533-1542.

Lindner, H.R., Tsafriri, A., Lieberman, M.E., Zor, U., Koch, Y., Bauminger, S., Barnea, A. (1974) Gonadotropin action on cultured Graafian follicles: induction of maturation division of the mammalian oocyte and differentiation of the luteal cell. Recent Prog. Horm. Res. 30, 79-127.

Lipner, H. \& Wendelken, L. (1971) Inhibition of ovulation by inhibition of steroidogenesis in immature rats. Proc. Soc. exp. Biol. Med. 136, 1141-1145.
Lowry, O.H., Rosebrough, N.J., Farr, A.L. \& Randall, R.J. (1951) Protein measurement with the Folin phenol reagent. J. biol. Chem. 193, 265-275.

Mori, T., Suzuki, A., Nishimura, T. \& Kambegawa, A. (1977) Evidence for androgen participation in induced ovulation in immature rats. Endocrinology 101, 623-626.

Murdoch, W.J., Peterson, T.A., Van Kirk, E.A., Vincent, D.L. \& Inskeep, E.K. (1986) Interactive roles of progesterone, prostaglandins, and collagenase in the ovulatory mechanism of the ewe. Biol. Reprod. 35, 1187-1194.

Pestka, S. (1971) Inhibitors of ribosome functions. Ann. Rev. Microbiol. 25, 697-710.

Pong, S., Hong, S.L. \& Levine, L. (1977) Prostaglandin production by methylcholantrene-transformed mouse BALB/3T3, J. biol. Chem. 5, 267-274.

Pool, W.R. \& Lipner, H. (1966) Inhibition of ovulation by antibiotics. Endocrinology 79, 858-864.

Rapoport, B. \& Adams, R.J. (1976) Induction of refractoriness to thyrotropin stimulation in cultured thyroid cells. Dependence on new protein synthesis. $J$. biol. Chem. 251, 6653-6661.

Reich, R., Tsafriri, A. \& Mechanic, G.L. (1985) The involvement of collagenolysis in ovulation in the rat. Endocrinology 116, 522-527.

Rotman, B. \& Papermaster, B.W. (1966) Membrane properties of living mammalian cells as studied by enzymatic hydrolysis of fluorogenic esters. Proc. natn. Acad. Sci. U.S.A. 55, $134-141$.

Snyder, B.W., Beecham, G.D. \& Schane, H.P. (1984) Inhibition of ovulation in rats with Epostane, an inhibitor of 3-beta-hydroxysteroid dehydrogenase. Proc. Soc. exp. Biol. Med. 176, 238-242.

Theodorsson-Norheim, E. (1986) Kruskal-Wallis test: BASIC computer program to perform nonparametric one-way analysis of variance and multiple comparisons on ranks of several independent samples. Comp. Meth. Progr. Res. 23, 57-62.

Toaff, M.E., Strauss, J.F., III, Flickinger, G.L. \& Shatti, S.J. (1979) Relationship of cholesterol supply to luteal mitochondrial steroid synthesis. J. biol. Chem. 25, 3977-3982.

Tsafriri, A. \& Kraicer, P.F. (1972) The time sequence of ovum maturation in the rat. J. Reprod. Fert. 29, 387393.

Tsafriri, A., Lieberman, M.E., Barnea, A., Bauminger, S. \& Lindner, H.R. (1973) Induction by luteinizing hormone of ovum maturation and steroidogenesis in isolated Graafian follicles of the rat: role of RNA and protein synthesis. Endocrinology 93, 1378-1386.

Wang, S.C. \& Greenwald, G.S. (1985) Effect of cycloheximide injected at proestrus on ovarian protein synthesis, peptide and steroid hormone levels, and ovulation in the hamster. Biol. Reprod. 33, 201-211.

Young, C.W., Robinson, P.F. \& Sacktor, B. (1963) Inhibition of the synthesis of protein in intact animals by acetoxycycloheximide and a metabolic derangement concomitant with this blockade. Biochem. Pharmacol. 12, 855-865.

Received 13 May 1988 